\title{
Facilitating Regeneration of an Iconic Canopy Species with Specific Niche Requirements
}

\author{
Katinka X. Ruthrof ${ }^{1}$, George Matusick ${ }^{1,2}$, Leonie E. Valentine ${ }^{1,3}$, Giles E. St. J. Hardy ${ }^{1}$ \\ ${ }^{1}$ School of Veterinary and Life Sciences, Murdoch University, Perth, Australia \\ ${ }^{2}$ The Nature Conservancy, Georgia Chapter, Chattahoochee Fall Line Conservation Office, Fort Benning, \\ GA, USA \\ ${ }^{3}$ NERP Environmental Decisions Hub, School of Plant Biology, University of Western Australia, Perth, Australia \\ Email: k.ruthrof@murdoch.edu.au
}

Received 26 February 2015; accepted 7 April 2015; published 9 April 2015

Copyright (C) 2015 by authors and Scientific Research Publishing Inc.

This work is licensed under the Creative Commons Attribution International License (CC BY). http://creativecommons.org/licenses/by/4.0/

(c) (i) Open Access

\section{Abstract}

Natural regeneration is a critical component of forest ecosystems sustainability. Local extinction can occur without adequate regenerationor seedling recruitment prior to adult senescence. The urban and peri-urban environment is particularly challenging for recruitment. For example, although many forest species have specific requirements involving fire events, few opportunities associated with fire exist in contemporary urban and peri-urban environments. For our study species, Eucalyptus gomphocephala, en masse recruitment can occur in ashbeds following a hot fire. However, this may not occur following low-intensity, fuel reduction burns that are prescribed for many E. gomphocephala woodlands and forests. Nevertheless, ashbeds could be created by constructing and burning coarse woody debris (CWD) piles. In a series of collaborative case studies involving community groups, NGOs and Local and State Government agencies, we investigated whether seedling recruitment could be facilitated through broadcast seeding after: a) creating CWD piles prior to a low intensity, prescribed burn; b) naturally-occurring ashbeds following a hot summer wildfire; and c) creating CWD piles and then burning the piles only. We found that regeneration of this post-fire, canopy gap regenerator can be facilitated by broadcast seeding naturally occurring or created ashbeds. However, it seems that protection from seed harvesters and herbivores is vital. These case studies provide tools that can be used to preserve the natural demographics in populations with specific regeneration requirements in a range of environments by leveraging natural recruitment processes and community involvement. Importantly, it is the conservation of these urban and peri-urban ecosystems that will be vital in maintaining connection between people and the environment into the future. 


\section{Keywords}

\section{Ashbed, Fire, Eucalyptus gomphocephala, Community Involvement, Restoration}

\section{Introduction}

Regeneration is necessary for sustained forest conservation. Lack of regeneration or recruitment can result in even-aged, older populations, and lead to arrested succession or local extinction if adult plants senesce before replacement (Ne'eman et al., 1999; Acacio et al., 2007). Post-fire recruitment is vital for many serotinous species, and this ability to retain seeds in the canopy is widespread in ecosystems in Australia, South Africa (Lamont et al., 1991; Gill, 1997), coniferous forests in California (Ne'eman et al., 1999), and in the Middle East (Tapias et al., 2004). However, altered fire regimes have been associated with recruitment limitation in a wide range of forest and woodland types, including temperate eucalypt woodlands (Yates and Hobbs, 1997; Yates et al., 1994), Proteaceous shrublands, Banksia woodland and Allocasuarina shrubland in Australia (Prober and Smith, 2009) and Quercus marilandica and Q. stallata forest in the eastern deciduous forest biome of North America (DeSantis et al., 2011). An understanding of regeneration niche requirements is fundamental to the ongoing management of forest communities.

Contemporary urban ecosystems that have become highly fragmented can be particularly hostile to natural recruitment. Fire, for example, can become almost eliminated from fragmented systems because of the lack of continuous vegetation cover and the cessation of active fire management (Hobbs and Yates, 2003; Prober and Smith, 2009). In addition, the drivers of fire ignition and spread have also changed as a result of landscape fragmentation, grazing by introduced herbivores, and weed invasion, and collectively these can lead to altered fire return intervals (Yates and Hobbs, 1997; Hobbs and Yates, 2003; Prober and Smith, 2009). The reintroduction of ecosystem processes, such as well-planned prescribed fire, could facilitate natural regeneration. However, treatment with low intensity surface fires aimed at fuel reduction may be inadequate in time and space to facilitate recruitment of some species (Ruthrof et al., 2013b). For example, low intensity surface fires under prescribed conditions may be inadequate for those species requiring ashbeds (sometimes called turkey heaps or slash piles), which are only created through high intensity soil heating (Burrows et al., 1990). Artificially creating ashbeds, though manual concentration of coarse woody debris prior to prescribed burns, represents one silvicultural method for facilitating recruitment.

The aim of this study was to examine a range of inexpensive methods for facilitating regeneration of a key canopy species, Eucalyptus gomphocephala, DC., which requires ashbeds for successful recruitment. One critical objective of this work was to involve and gain assistance from community groups, Local and State Government agencies in order to facilitate adoption. Our series of case studies investigated whether regeneration could be facilitated through broadcast seeding after: a) the creation of coarse woody debris (CWD) piles prior to a low intensity, prescribed burn; b) naturally-occurring ashbeds following a hot summer wildfire; and c) creating CWD piles and then burning the piles only.

\section{Materials and Methods}

\subsection{Study Species and Region}

Eucalyptus gomphocephala (tuart) is a dominant or co-dominant woodland and forest canopy tree endemic to southwestern Australia. Eucalyptus gomphocephala woodlands provide important landscape, cultural, social and economic values. Since settlement, approximately65\% of these woodlands have been lost to clearing for urbanisation and agriculture (TRG, 2002). In addition to this, many of these woodlands and forests have failed to regenerate for many decades which is concerning to many conservationists, managers and researchers. Eucalyptus gomphocephala has life history characteristics similar to other temperate eucalypts (Ruthrof et al., 2003). It is a post-fire, canopy gap regenerator, with en masse recruitment occurring in cohorts onashbeds following fire, serotinous seed fall, satiation of seed predators (such as ants), and the creation of a transient soil seed bank lasting 6 - 12 months (Ruthrof et al., 2002).

The study region is characterised by a Mediterranean climate with hot dry summers and mild wet winters. 
Most (80\%) of rainfall falls between May and September. The study sites occur on the Spearwood Dune System of the Swan Coastal Plain, with variable depths of siliceous, brown and yellow leached yellow sands (McArthur and Bettenay, 1974).

\subsection{Study Sites and Experimental Design}

\subsubsection{Creation of Coarse Woody Debris (CWD) Piles Prior to a Low Intensity, Prescribed Burn} Paganoni Swamp (32 26'40.22"S, $115^{\circ} 47^{\prime} 15.80^{\prime \prime E}$ ) (Paganoni) is a 700 ha, high quality Eucalyptus-Banksia-Allocasuarina woodland located $53 \mathrm{~km}$ SSW of Perth, in southwestern Australia. This woodland contains a large and significant population of Eucalyptus gomphocephala but regeneration is sparse and inadequate for sustaining the woodland structure. A low intensity, prescribed burn was planned by the State Government environmental agency (Department of Parks and Wildlife-DPaW) in May 2011. The prescribed burn was used as an opportunity to explore methods of facilitating regeneration of E. gomphocephala.

Twelve CWD piles were created prior to the prescribed burn. Given that machinery was not permitted in Paganoni, ashbeds were be created by hand by collecting coarse woody debris (CWD) ( 1 cm - $20 \mathrm{~cm}$ width), and placing it into $5 \mathrm{~m} \times 5 \mathrm{~m}(\times 1.0 \mathrm{~m}$ high) marked plots within canopy gaps. A local community group (the Friends of Paganoni Swamp), DPaW, a state-funded unemployment group (Now Green Team) and a number of students were involved in creating the CWD piles over two days. Broadcast seeding (plus chaff) of E. gomphocephala was carried out at typical eucalypt forestry quantities ( 150,000 seeds/ha) following the prescribed burn (May 2011) as soon as the ashbeds were cool (late May 2011). Seeds were available for the three case studies through a community outreach seed collection program which is run by the authors collaboratively with local government agencies (the City of Mandurah and the City of Rockingham). Plots were monitored at 4 and 16 months for the presence of $E$. gomphocephala seedlings. Other information noted at the sites included the number of ant middens in $5 \mathrm{~m} \times 5 \mathrm{~m}$ plots on, and adjacent to, each ashbed.

\subsubsection{Naturally Occurring Ashbeds Following a Hot Summer Wildfire}

Rockingham Lake Regional Park ( $32^{\circ} 16^{\prime} 41.96 " S$, $115^{\circ} 46^{\prime} 33.78^{\prime \prime E}$ ) (Dixon Road) is a 4270 ha peri-urban Eucalyptus-Melaleuca dominated reserve, located $37 \mathrm{~km}$ SSW of Perth, in southwestern Australia. A hot summer wildfire occurred in January 2013. Usually, the timing of this fire would be suitable for recruitment of $E$. gomphocephala seeds, as any serotinous seeds would fall in January and would last 6 - 12 months in a temporary soil seed reserve (Ruthrof et al., 2002), in time for the winter rains to being in May. However, the population of E. gomphocephala in this woodland suffered a severe and sudden dieback event coinciding with extreme drought and heat conditions in early 2011 (Matusick et al., 2012) and thus did not have a serotinous seed store. The wildfire was seen as an opportunity to facilitate regeneration using collected seed. A local community group (Friends of Paganoni Swamp) and the Local Government agency (the City of Rockingham) were involved in locating and seeding ashbeds in April 2013. A number of relatively small (size $\sim 7 \mathrm{~m}^{2}$ ) ashbeds were found and their location noted using a GPS (Garmin). Each ashbed was raked, broadcast seeded with E. gomphocephala seeds (+chaff), and then lightly raked again to protect seeds from seed harvesters. Ashbeds $(n=23)$ were revisited after two and 16 months to monitor seedling emergence and survival.

\subsubsection{Creating Coarse Woody Debris Piles and Then Burning the Piles Only}

Yalgorup National Park (32 42'47.43"S, $\left.115^{\circ} 37^{\prime} 55.56 " E\right)$ is a Eucalyptus-Banksia-Melaleuca mixed woodland and heath of 12,000 ha located $87 \mathrm{~km}$ SSW of Perth, in southwestern Australia. Certain parts of the National Park are highly degraded from historical cattle grazing and were highlighted for revegetation by an NGO in the region, The Peel Harvey Catchment Council. In May 2013, as part of this revegetation program, approximately 40 CWD piles $(6 \mathrm{~m} \times 6 \mathrm{~m} \times 1 \mathrm{~m}$ high) were created $(\sim 1 \mathrm{~cm}-30 \mathrm{~cm}$ in width) by hand and machinery, then burnt and seeded with E. gomphocephala seeds (plus chaff) in June 2013as soon as ashbeds were cool. This was undertaken with the assistance of the Local Government agency (the City of Mandurah), the State Government environmental agency (DPaW), university students and a local community group (the Friends of Island Point). Nine ashbeds were monitored for seedling emergence and survival at 6 and 15 months.

\section{Results}

At Paganoni, successful E. gomphocephala germination was recorded in the ashbeds that were created during 
the prescribed burn (Figure 1). However, there were few survivors after 16 months. There were significantly more ant middens on ashbeds than in adjacent control plots of equal size (mean $2.2 \pm 0.5 \mathrm{SE}$ and $0.3 \pm 0.2$, respectively). At Dixon Road, following the wildfire, successful seedling germination was also recorded, however, this number declined substantially by 16 months. Rabbit herbivory of several seedlings was noted. At Yalgorup, the created ashbeds contained a higher number of seedlings, relative to the other two trails, and maintained this number over time.

\section{Discussion}

This study has shown that regeneration of this post-fire, canopy gap regenerator can be facilitated by broadcast seeding into naturally occurring or created ashbeds. Mass regeneration of E. gomphocephala in ashbeds has been noted previously following wildfires; for example, in Yalgorup National Park, a summer wildfire in 1996 led to 0.33 seedlings $/ \mathrm{m}^{2}$ in 1998 and this level was maintained till 2003 at 0.31 seedlings $/ \mathrm{m}^{2}$ (Ruthrof, 2003). High densities of seedlings have also been recorded on created ashbeds in Ludlow Tuart Forest (3 to $28 / \mathrm{m}^{2}$, mean of $11.5 \pm 3.1 / \mathrm{m}^{2}$ Ruthrof, unpub. results). However, in these studies, the seed originated from the extant canopy. This is the first study to treat a variety of ashbed types with seed.

The ashbed effect on the regeneration and growth of many species of Eucalyptus has long been recognized (Burrows et al., 1990). Ashton (1956) and Grose (1960) have shown that E. regnans regenerates naturally only after a major disturbance such as fire and Burrows et al. (1990) demonstrated that $E$. wandoo regeneration can be successfully obtained on ashbeds using serotinous seed and result in high densities (14 - 17 seedlings $/ \mathrm{m}^{2}$ at six months after fire and $5-10 / \mathrm{m}^{2}$ at 14 months after fire). These are similar numbers to those seen in E. gomphocephala in the current study in Yalgorup. Ashbeds increase the success of regeneration through firstly, increasing the available N and P (Humphreys and Lambert, 1965). Secondly, fire can destroy biological opposition to recruitment, such as soil-litter microorganisms, pathogens and herbivores (Renbuss et al., 1973). Thirdly, fire reduces bulk density, increases water infiltration and increases water availability (Hatch, 1960; Ruthrof et al., 2013a). Fourthly, it removes competition from surrounding vegetation for limited resources such a light, nutrients and water (Wellington and Noble, 1985). Fifthly, (Loneragan and Loneragan, 1964) suggested possible mycorrhizal symbiosis in seedlings growing on ashbeds. Together, these factors can result in the mass recruitment of seedlings on ashbeds and sparse recruitment off ashbeds (Burrows et al., 1990).

In the current study, regeneration density in Yalgorup was maintained at high levels for the course of the study compared with the other sites. One reason for this could be the amount and size of material used to construct the CWD piles. This was larger than in Paganoni as machinery such as tractors and chainsaws were permitted at Yalgorup. Combustion of larger CWD would provide sufficiently long duration of high temperatures to cause the physical and chemical changes needed for ashbed creation (Burrows et al., 1990). The minimum size and temperature of ashbed creation requires further work in this restoration context. Regardless, the ashbed creation activity and study was deemed so successful that the NGO involved created a training video to assist other groups and agencies in creating ashbeds. It is a freely available You Tube video:

https://www.youtube.com/watch?v=IFBeuzrojso\&feature=c4-overview\&list=UUTFgDmpoxSTT_0LdbO8CP3g

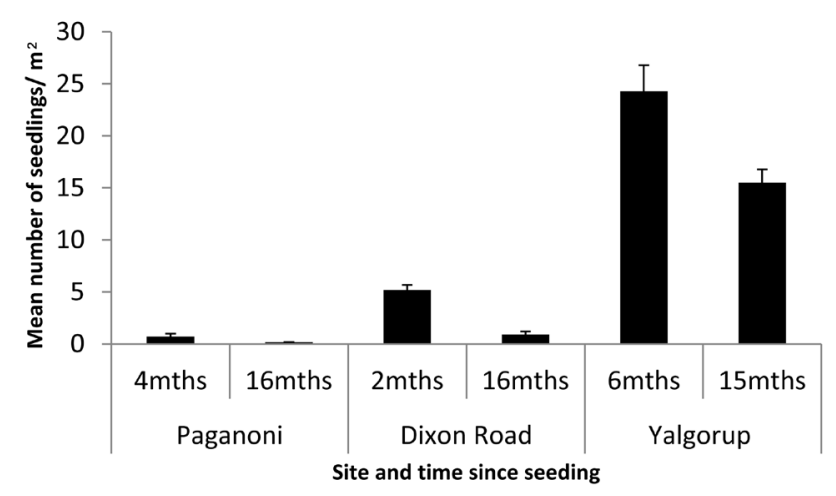

Figure 1. Mean number of seedlings $/ \mathrm{m}^{2}$ ( \pm one standard error) following creation of ashbeds and broadcast seeding with Eucalyptus gomphocephala after creation of CWD piles prior to: a) a low intensity prescribed burn (Paganoni); b) naturally occurring ashbeds following a hot summer wildfire (Dixon Road) and c) creating CWD piles and then burning piles only (Yalgorup), in southwestern Australia. 
There are a number of factors that could have influenced the low numbers of recruited seedlings at Paganoni and Dixon Road. At Paganoni, there were significantly more ant middens recorded on ashbeds than off the ashbeds. Ants are perhaps attracted to the ashbeds because of ease of movement across a simplified landscape caused by the elimination of litter, the changes in food and shelter availability, changes in environmental conditions and altered litter (Andersen, 1988), or perhaps because the bulk density in these areas is lower (Ruthrof et al., 2013a) and it is thus easier to build middens. Ants are known as one of the most significant post-dispersal seed harvesters in eucalypt communities, often removing large quantities of seed from the ground (Ashton, 1979; Andersen and Ashton, 1985; Yates et al., 1995) seed harvesters of E. gomphocephala (Ruthrof et al., 2002). Given the potential for ants to reduce seeds from entering the recruitment pool, and following the low levels of seedling establishment at Paganoni, seed is now lightly raked following broadcast seeding into ashbeds to protect seeds from seed harvesters.

Recruitment could have been low at both Paganoni and Dixon Road due to grazing by herbivores. In this case, invasive rabbits were suspected as some seedlings were grazed. Grazing by the introduced rabbit has been shown to be a major degrading force in Australian ecosystems (Yates et al., 2000) and one of the biggest threats to regeneration in temperate eucalypt communities (Yates and Hobbs, 1997) and in urban ecosystems (Ruthrof et al., 2013b; Standish et al., 2012; Close et al., 2009). Although the cost of herbivore baiting or fencing is considerably high, failure to control these may jeopardize the success of restoration projects (Yates et al., 2000) and will need to be addressed to reduce this pressure in the future.

This project also demonstrated that a collaborative, multi-agency and community project can be successful in terms of developing connections between groups and developing positive outcomes for urban and peri-urban ecosystems. The commitment to, and success of, restoration projects could be enhanced through the development of a beneficial relationship between humans and the natural environment (Geist and Galatowitsch, 1999). The community benefits from being involved with restoration projects through, amongst other things, developing community spirit, improving agency-community relations (Ryan and Hamin, 2008) and providing psychological and physiological benefits (Geist and Galatowitsch, 1999). The project sites benefit from the participation of hard working, enthusiastic people with a depth of local knowledge, experience and a sense of stewardship that can drive the sustained support for longer-term projects (Ruthrof and Valentine, 2010).

\section{Conclusion}

Long term persistence of woodlands and forests is threatened by a lack of regeneration. Our study has shown that regeneration of this post-fire, canopy gap regenerator can be facilitated by broadcast seeding naturally occurring or created ashbeds. Protection from seed harvesters and herbivores is vital. An understanding of the regeneration niche helps increase success. We have provided inexpensive tools to preserve these post-fire regenerating populations in urban and peri-urban environments and shown that this can be carried out collaboratively with State and Local Government agencies, NGOs, community groups and private landowners. It is the conservation of these urban and peri-urban ecosystems that will be vital in maintaining connection between people and the environment into the future.

\section{Acknowledgements}

The authors thank Friends of Paganoni Swamp (particularly Leonie Stubbs), Friends of Island Point, Men of the Trees Peel Branch, City of Rockingham, City of Mandurah, Peel Harvey Catchment Council, Department of Parks and Wildlife, Now Green Teams Rockingham and Peel, Murdoch Tafe, Veronica Ingrilli, Marleen Buizer, Niels Brouwers, Annora Longhurstand Idger Zwiers. Funds for the Paganoni Swamp project were awarded through the 2011 Department of Environment and Conservation (now DPaW) Environment Community Grant through the Friends of Paganoni Swamp. Funds for the Yalgorup National Park project were awarded through a Federal Government Caring for our Country Grant through the Peel Harvey Catchment Council.

\section{References}

Acacio, V., Holmgren, M., Jansen, P. A., \& Schrotter, O. (2007). Multiple Recruitment Limitation Causes Arrested Succession in Mediterranean Cork Oak Systems. Ecosystems, 10, 1220-1230. http://dx.doi.org/10.1007/s10021-007-9089-9

Andersen, A. N. (1988). Immediate and Longer-Term Effects of Fire on Seed Predation by Ants in Sclerophyllous Vegetation in Southeastern Australia. Australian Journal of Ecology, 13, 285-293.

http://dx.doi.org/10.1111/j.1442-9993.1988.tb00976.x 
Andersen, A. N., \& Ashton, D. H. (1985). Rates of Seed Removal by Ants at Heath and Woodland Sites in Southeastern Australia. Australian Journal of Ecology, 10, 381-390. http://dx.doi.org/10.1111/j.1442-9993.1985.tb00900.x

Ashton, D. H. (1956). Studies on Autecology of Eucalyptus regnans. PhD, Melbourne: University of Melbourne.

Ashton, D. H. (1979). Seed Harvesting by Ants in Forests of Eucalyptus-Regnans F Muell in Central Victoria. Australian Journal of Ecology, 4, 265-277. http://dx.doi.org/10.1111/j.1442-9993.1979.tb01218.x

Burrows, N., Gardiner, G., Ward, S., \& Robinson, A. (1990). Regeneration of Eucalyptus wandoo Following Fire. Australian Forestry, 53, 248-258. http://dx.doi.org/10.1080/00049158.1990.10676084

Close, D. C., Ruthrof, K. X., Turner, S., Rokich, D. P., \& Dixon, K. W. (2009). Ecophysiology of Species with Distinct Leaf Morphologies: Effects of Plastic and Shadecloth Tree Guards. Restoration Ecology, 17, 33-41.

http://dx.doi.org/10.1111/j.1526-100X.2007.00330.x

DeSantis, R. D., Hallgren, S. W., \& Stahle, D. W. (2011). Drought and Fire Suppression Lead to Rapid Forest Composition Change in a Forest-Prairie Ecotone. Forest Ecology and Management, 261, 1833-1840. http://dx.doi.org/10.1016/j.foreco.2011.02.006

Geist, C., \& Galatowitsch, S. M. (1999). Reciprocal Model for Meeting Ecological and Human Needs in Restoration Projects. Conservation Biology, 13, 970-979. http://dx.doi.org/10.1046/j.1523-1739.1999.98074.x

Gill, A. M. (1997). Eucalypts and Fires, Interdependent or Independent? In J. E. Williams, \& J. C. Z. Woinarski (Eds.), Eucalypt Ecology: Individuals to Ecosystems (pp. 151-167). Melbourne: Cambridge University Press.

Grose, R. J. (1960). Effective Seed Supply for the Natural Regeneration of Eucalyptus delegatensis R. T. Baker syn. Eucalyptus gigantea Hook.f. APPITA, 13, 141-147.

Hatch, A. B. (1960). Ash Bed Effects in Western Australian Forest Soils. Bulletin of Forest Department of Western Australian, 64, 19.

Hobbs, R. J., \& Yates, C. J. (2003). Impacts of Ecosystem Fragmentation on Plant Populations: Generalising the Idiosyncratic. Australian Journal of Botany, 51, 471-488. http://dx.doi.org/10.1071/BT03037

Humphreys, F. R., \& Lambert, M. J. (1965). An Examination of a Forest Site Which Has Exhibited the Ash Bed Effect. Australian Journal of Soil Research, 3, 81-94. http://dx.doi.org/10.1071/SR9650081

Lamont, B. B., Lemaitre, D. C., Cowling, R. M., \& Enright, N. J. (1991). Canopy Seed Storage in Woody-Plants. The Botanical Review, 57, 277-317. http://dx.doi.org/10.1007/BF02858770

Loneragan, O. W., \& Loneragan, J. F. (1964). Ash-Bed and Nutrients in the Growth of Seedlings of Karri (Eucalyptus diversicolor E.v.M.). Journal of the Royal Society of Western Australia, 47, 75-80.

Matusick, G., Ruthrof, K. X., \& Hardy, G. (2012). Drought and Heat Triggers Sudden and Severe Dieback in a Dominant Mediterranean-Type Woodland Species. Open Journal of Forestry, 2, 183-186. http://dx.doi.org/10.4236/ojf.2012.24022

McArthur, W. M., \& Bettenay, E. (1974). The Development and Distribution of Soils on the Swan Coastal Plain, Western Australia. Publication No.16, CSIRO, Melbourne.

Ne'eman, G., Fotheringham, C. J., \& Keeley, J. E. (1999). Patch to Landscape Patterns in Post Fire Recruitment of a Serotinous Conifer. Plant Ecology, 145, 235-242. http://dx.doi.org/10.1023/A:1009869803192

Prober, S. M., \& Smith, F. P. (2009). Enhancing Biodiversity Persistence in Intensively Used Agricultural Landscapes: A Synthesis of 30 Years of Research in the Western Australian Wheatbelt. Agriculture Ecosystems \& Environment, 132, 173-191. http://dx.doi.org/10.1016/j.agee.2009.04.005

Renbuss, M. A., Chilvers, G. A., \& Pryor, L. D. (1973). Microbiology of an Ash-Bed. Proceedings of the Linnean Society of New South Wales, 97, 302-310.

Ruthrof, K. X. (2003). Seedling Survival, Growth and Health of Eucalyptus gomphocephala (Tuart) Seedlings in Yalgorup National Park. Botanic Gardens and Parks Authority, 12 p.

Ruthrof, K. X., Fontaine, J. B., Buizer, M., Matusick, G., McHenry, M. P., \& Hardy, G. E. S. (2013a). Linking Restoration Outcomes with Mechanism: The Role of Site Preparation, Fertilisation and Revegetation Timing Relative to Soil Density and Water Content. Plant Ecology, 214, 987-998. http://dx.doi.org/10.1007/s11258-013-0224-8

Ruthrof, K. X., Loneragan, W. A., \& Yates, C. J. (2003). Comparative Population Dynamics of Eucalyptus cladocalyx in Its Native Habitat and as an Invasive Species in an Urban Bushland in South-Western Australia. Diversity and Distributions, 9, 469-483. http://dx.doi.org/10.1046/j.1472-4642.2003.00040.x

Ruthrof, K. X., Renton, M., \& Dixon, K. (2013b). Overcoming Restoration Thresholds and Increasing Revegetation Success for a Range of Canopy Species in a Degraded Urban Mediterranean-Type Woodland Ecosystem. Australian Journal of Botany, 61, 139-147. http://dx.doi.org/10.1071/BT12297

Ruthrof, K. X., \& Valentine, L. E. (2010). Ecological, Economic and Social Challenges, Restoration Filters and Planning for the Unknown. Australian Plant Conservation, 19, 34-35.

Ruthrof, K. X., Yates, C. J., \& Loneragan, W. A. (2002). The Biology of Eucalyptus gomphocephala DC. (Tuart). In B. J. Keighery, \& V. M. Longman (Eds.), Tuart (Eucalyptus gomphocephala) and Tuart Communities (pp. 108-122). Perth: Wildflower Society of Western Australia (Inc.). 
Ryan, R. L., \& Hamin, E. (2008). Wildfires, Communities, and Agencies: Stakeholders’ Perceptions of Post-Fire Forest Restoration and Rehabilitation. Journal of Forestry, 106, 370-379.

Standish, R. J., Fontaine, J. B., Harris, R. J., Stock, W. D., \& Hobbs, R. J. (2012). Interactive Effects of Altered Rainfall and Simulated Nitrogen Deposition on Seedling Establishment in a Global Biodiversity Hotspot. Oikos, 121, 2014-2025. http://dx.doi.org/10.1111/j.1600-0706.2012.20553.x

Tapias, R., Climent, J., Pardos, J. A., \& Gil, L. (2004). Life Histories of Mediterranean Pines. Plant Ecology, 171, 53-68. http://dx.doi.org/10.1023/B:VEGE.0000029383.72609.f0

TRG (2002). Status Report: Tuart Conservation and Protection. Tuart Response Group, Department of Conservation and Land Management.

Wellington, A. B., \& Noble, I. R. (1985). Post-Fire Recruitment and Mortality in a Population of the Mallee Eucalyptus incrassata in Semi-Arid, South-Eastern Australia. Journal of Ecology, 73, 645-656.

Yates, C. J., \& Hobbs, R. J. (1997). Temperate Eucalypt Woodlands: A Review of Their Status, Processes Threatening Their Persistence and Techniques for Restoration. Australian Journal of Botany, 45, 949-973. http://dx.doi.org/10.1071/BT96091

Yates, C. J., Hobbs, R. J., \& Atkins, I. (2000). Establishment of Perennial Shrub and Tree Species in Degraded Eucalyptus salmonophloia (Salmon gum) Remnant Woodlands: Effects of Restoration Treatments. Restoration Ecology, 8, 135-143. http://dx.doi.org/10.1046/j.1526-100x.2000.80020.x

Yates, C. J., Hobbs, R. J., \& Bell, R. W. (1994). Landscape-Scale Disturbances and Regeneration in Semi-Arid Woodlands of South Western Australia. Pacific Conservation Biology, 1, 214-221.

Yates, C. J., Taplin, R., Hobbs, R. J., \& Bell, R. W. (1995). Factors Limiting the Recruitment of Eucalyptus salmonophloia in Remnant Woodlands. 2. Post-Dispersal Seed Predation and Soil Seed Reserves. Australian Journal of Botany, 43, 145155. http://dx.doi.org/10.1071/BT9950145 